\title{
FLOWER VISITS OF INSECTS
}

\author{
By Charles Robertson
}

Carlinville, Illinois.

In the study of the pollination of flowers by insects (6) a good many observations have been made which relate primarily to the habits of insects and only indirectly, if at all, to the elucidation of insect flowers. It is proposed here to consider the data from the standpoint of the insects.

The flower groups adopted are divided into a social set, whose flowers are in heads, spikes or close umbels, so that insects pass from one to another without taking wing or climbing, and a non-social set. The latter contains 54.4 per cent of the flowers, and is divided into $\mathrm{Ma}$, long-tongued bee flowers, including 11 adapted to birds, hawk-moths and butterflies, and Mi, shorttongued bee flowers, including six fly flowers. The social set includes Mas, long-tongued bee flowers; Mis, short-tongued bee flowers; and Pol, visited by miscellaneous short-tongued insects.

The insect visits were first distributed under Müller's flower classes. These were then divided into non-social and social sets and the visits were distributed again under them. Of 9 cases, maxima under $\mathrm{Hb}$ fell under non-social $\mathrm{Hb}$ in 6 . In 27 other cases, however, maxima under $\mathrm{B}, \mathrm{AB}$, or $\mathrm{A}$ always fell under the social sets.

The percentages for each class and color and the visits observed are:

\begin{tabular}{|c|c|c|c|c|c|c|c|c|c|}
\hline & \multicolumn{2}{|c|}{ Non-social } & \multicolumn{3}{|c|}{ Social } & \multirow[t]{2}{*}{ Total } & \multicolumn{3}{|c|}{ Colors } \\
\hline & $\mathrm{Ma}$ & $\mathrm{Mi}$ & Mas & Mis & Pol & & Red & White & Yellow \\
\hline $\begin{array}{l}\text { L.ocal Flora } \\
\text { Flowers observed } \\
\text { Before July } \\
\text { After June }\end{array}$ & $\begin{array}{l}28.3 \\
30.2 \\
28.9 \\
30.5\end{array}$ & $\begin{array}{l}27.9 \\
24.2 \\
32.3 \\
15.2\end{array}$ & $\left|\begin{array}{l}16.4 \\
18.7 \\
11.0 \\
28.2\end{array}\right|$ & $\begin{array}{l}22.0 \\
21.5 \\
22.9 \\
19.0\end{array}$ & $\begin{array}{l}5.1 \\
5.2 \\
4.6 \\
6.8\end{array}$ & $\begin{array}{l}540 \\
437 \\
235 \\
262\end{array}$ & $\mid \begin{array}{l}29.2 \\
30.2 \\
26.3 \\
34.3\end{array}$ & $\begin{array}{l}39.6 \\
39.1 \\
44.6 \\
33.5\end{array}$ & $\begin{array}{l}31.1 \\
30.6 \\
28.9 \\
32.0\end{array}$ \\
\hline $\begin{array}{l}\text { Pollinating visits } \\
\text { Non-pollinating visits }\end{array}$ & $\begin{array}{r}7.5 \\
41.1\end{array}$ & $\begin{array}{r}13.3 \\
9.5\end{array}$ & $\mid \begin{array}{l}20.4 \\
31.3\end{array}$ & $\begin{array}{l}39.8 \\
10.9\end{array}$ & & \begin{tabular}{l|r|}
7 & 13971 \\
0 & 852
\end{tabular} & $\begin{array}{l}16.8 \\
46.3\end{array}$ & $\begin{array}{l}51.3 \\
33.3\end{array}$ & $\begin{array}{l}31.7 \\
20.3\end{array}$ \\
\hline
\end{tabular}


Percentages of visits to red flowers are given for the Berlin Garden and Low Germany (Loew 2,3) and the Alps (Müller 5,512-23). The percentages of red flowers observed are for the Alps 41.6 and Berlin Garden 48.2. In 31 cases, all except Sphingidæ, the percentage of local visits to red ranges from 5.4 to 51.3 less, or an average of 24 . The term preference, as used here, means only that the percentage of visits is greater than the percentage of flowers observed. For each group the percentages of flowers visited as well as the visits were distributed under each flower class. Usually these are much alike, so that the percentages of flowers visited are not mentioned except when they are quite different from the visits.

The flowers were also divided into an early group containing 235 plants, 142 blooming, and 33 observed, before July, and a late group containing 262 plants, 144 blooming, and 58 observed, after June. In the case of 60 plants the visits observed before July and after June were referred to each group. Of these 60 plants 13 are not native. Visits to these groups were first distributed under Müller's classes. Before July there are maxima under $\mathrm{B}, \mathrm{AB}$, including $\mathrm{Po}$, and $\mathrm{A}$. After June there is a slight increase in $\mathrm{Hb}$, including $\mathrm{O}$ and $\mathrm{F}$, and a marked increase in $\mathrm{B}^{\prime}$.

The visits to these groups were also distributed under the new classes. The early group shows maxima of the simplest flowers, non-social Mi, and white colors. These along with Mis decrease in the late group, which shows maxima of Ma and red, and a great increase in Mas. The specialization of the late group is marked by the increase of the social flowers from 38.7 to 54.1 per cent.

When $\mathrm{B}^{\prime}$ as an element of the flora changes from 8.0 to 28.2 per cent, the maxima of the insect groups change from the four other dominant classes to $\mathrm{B}^{\prime}$. The only exceptions are the ruby-throated and the Non-aculeata. The maxima of the same insects, when distributed into early and late sets of the new categories, in 62.8 per cent of the cases, fall under the same flower groups.

The Bombidæ, Euceridæ, Anthophoroidea, Dasygastræ and long-tongued bees in general change from $\mathrm{Ma}$ to Mas, due to the fact that Mas is not well represented in the early flora. 
Apis mellifera, the Ceratinidæ and Bombyliidæ change from Mis to Mas. Early there is greater contrast between $\mathbf{M}$. and Mis than late between Mas and Mis. Consequently these mid-tongued insects are excluded from a considerable number of early $\mathrm{Ma}$, while they can reach the nectar of most of the late Mas. A like change in Melectoidea and Andrenidæ is owing to the fact that the late ones have longer tongues.

\section{BeEs.}

Apis mellifera.-Of 196 visits, 30.1 per cent are to Mis, 27.0 to Mas, 43.3 to white, 65.3 to social flowers and 28.3 to Compositæ. Of its pollen visits 36.7 per cent, while of its nectar visits 29.0, are under yellow. Red shows: local 24.4, Low Germany 47.3, Berlin Garden 55.0 and the Alps 60.7. Before July the hive-bee prefers Mis; after June, Mas, Mis and Pol. The maxima shiftfrom AB 33.3 to B' 44.7, Mis 32.2 to Mas 43.8.

An introduced domesticated insect, it is the most important single obstacle in the way of the anthecologist. It occupies an intermediate position between long-tongued and short-tongued bees, though it makes more visits to flowers preferred by the latter. On account of its abundance and long flight it makes more legitimate visits than any other insect, except Bombus americanorum.

It shows inferiority to several indigenous bees, Bombus, Melissodes, Megachile, Calliopsis andreniformis, in its inability to utilize some complicated flowers like Desmodium, but this is somewhat offset by its ingenuity in extracting pollen from Dicentra cucullaria.

Bombinae.-Of 717 visits to 273 flowers, 39.4 per cent are to Ma, 31.9 to Mas, 41.1 to red, 10.0 to Labiatæ, 10.6 to Leguminosæ and 25.2 to Compositæ. Visits to red are: Low Germany 61.5, Berlin Garden 63.7 and Alps 64.7. Four prefer Ma, four Mas, seven red and one yellow.

Loew $(\mathbf{2}, 87)$ states that since male bumblebees have shorter tongues than the workers, the relations holding for the females and workers do not apply to them, and that therefore they prefer flowers of class $\mathrm{B}^{\prime}$. This is not dependent upon the dif- 
ference in the length of the proboscis, but is largely a phenological matter connected with the late flight of the workers, after May 13 , still later flight of the males, after July 4, and the late blooming of $\mathrm{B}^{\prime}$ which is really a phenological class. The males only resemble bees in general in preferring $\mathrm{B}^{\prime}$ in their late visits. The percentage of visits to $\mathrm{B}^{\prime}$ after June is for the females 32.1, workers 38.1, and males 57.6. So that under the same conditions all three forms prefer $\mathrm{B}^{\prime}$. The females show a maximum under $\mathrm{Ma}, 47.3$, while the workers and males show maxima under Mas, 43.5 and 57.8 .

Seven species, forming 4 per cent of the long-tongued bees, make 23 per cent of the long-tongued bee visits, the average being 102. Bombus americanorum makes 227 visits, the highest number for any visitor. Bumblebees are the characteristic visitors of long-tongued bee flowers and have probably had more influence in producing such flowers than all other bees together. They make 39 per cent of the visits to $\mathrm{Ma}$, the highest specialized of non-social flowers.

Psithyrus.-Of 47 visits to 39 flowers, 61.7 per cent are to Mas, 87.2 to social flowers, 42.5 to Compositæ, 14.9 to Labiatæ and 12.7 to Leguminosæ.

Loew $(2,103)$ says: "the habit possessed by fomale bumblebees of chiefly seeking out hymenopterid flowers, while the males give preference to social flowers, is exaggerated in the parasitic genus Psithyrus, which constitutes a small side-branch of the group. The species of this genus consequently prefer dark-colored flowers even more than do the short-tongued species of Bombus."

The European visits for the females show 34.3 more in percentage of visits to $\mathrm{Hb}$ than to $\mathrm{B}$ ', while the local visits show only 6.0 more. In the local species the apparent preference for red flowers is not a consequence of a preference for $\mathrm{Hb}$ or of any difference in the visits of the males, for, while the males show 33.3 more in percentage of visits to $\mathrm{B}^{\prime}$ than the females do, they also show 15.1 more in percentage of visits to red. Local visits to red are 55.3 per cent, in the Berlin Garden 71.5, Low Germany 74.0 and the Alps 77.8. The visits of the males which fly late, do not differ from those of the females as much as the late visits 
of the females differ from the early ones. Visits to red show: females 51.5, males 66.6; females before July 71.4, after June 36.3 .

Bombida.-Before July the Bombidæ prefer Ma and red; after June, Mas, red and yellow. They show less preference for $\mathrm{B}^{\prime}$ than does any other considerable group of long-tongued bees. The maxima shift from $\mathrm{Hb} 59.8$ to $\mathrm{B}^{\prime} 42.0$, Ma 50.8 to Mas 48.6. Visits to yellow change from 19.6 to 34.0.

Apygidial Scopulipedes.-These show every indication of great age: the fragmentary nature and the marked structural differences of the still existing groups, as well as their wide and discontinuous distribution. Müller says that the maxillary palps of Bombus, etc. are aborted as a result of specialization of the proboscis, lengthening of the glossa and labial palps $(4,57)$. But it is evidently a mark of age, for many Pygidialia have the proboscis as long and even more highly specialized, but retain the primitive number of six joints. It seems that the Apygidialia were the primitive long-tongued bees and had most to do with the origin of the earliest long-tongued bee flowers. The specialized genera of Pygidialia are characterized by long tongues, rapid flight, rather short seasons, often oligolectic and more peculiar habits, just as would be expected of later developed competitors.

Anthophoridæ.-Of 75 visits to 56 flowers, 66.6 per cent are to Ma, 22.6 to Mas, 54.6 to red, 21.3 to Labiatæ, 16.0 to Leguminosæ and 10.6 each to Polemoniales and Personales.

Eucerida (521 visits to 202 flowers).-These prefer Mas, which shows 31.6 per cent of the flowers visited and 54.7 per cent of the visits, red 39.9 and yellow $35.7,10.5$ per cent of the visits being to Labiatæ and 40.8 to Compositæ. Twenty prefer Mas, $11 \mathrm{Ma}, 19$ red, 11 yellow, two white. Before July they prefer Ma, Mas and red; after June, Mas, yellow and red. The group is a late one. The maxima shift from $\mathrm{Hb} 60.3$ to $\mathrm{B}^{\prime} 51.8$, Ma 48.4 to Mas 66.2 , red 42.8 to yellow 41.0.

Emphoridoe.-Of 14 visits to 11 flowers, 57.1 per cent are to Ma, 35.7 to Mas, 57.1 to red, 42.8 to white, 28.5 to Polemoniales and 21.4 to Compositæ.

Anthophoroidea.-Of the 610 visits of the last three families, 50.3 per cent are to Mas, $42 .^{\prime}$ to red, 32.4 to yellow, 11.6 to 
Labiatæ and 35.7 to Compositæ. Before July they prefer Ma, Mas and red; after June, Mas, red and yellow. The maxima shift from $\mathrm{Hb} 68.9$ to $\mathrm{B}^{\prime}$ 49.0, Ma 56.1 to Mas 64.4.

Xylocopida.-The single species, Xylocopa virginica, near its northern limit here, is rare and its visits few. It seems to prefer Mas and red.

Ceratinidoe.-Of 194 visits to 162 flowers, 33.5 per cent are to Mis, 27.8 to Mi, 21.1 to Mas, 47.4 to white and 24.7 to Compositæ. The visits of the males differ remarkably from those of. the females and under similar conditions. The females show Mi 22.4, Mas 30.4, Mis 23.2 and red 32.5. The males show Mi 42.8, Mas 3.0, Mis 40.8 and red 14.2. In their visits they resemble the Halictidæ and Apis mellifera. Before July they prefer Mis, Mi, Pol, and white; after June, Mas, Mis and red. The maxima shift from $\mathrm{AB} 28.4$ to $\mathrm{B}^{\prime}$ 55.2, Mis 35.3 to Mas 52.2, white 50.7 to red 37.3.

Melectoidea (ex. Nomadidæ; 209 visits to 72 flowers).These prefer Mas 67.9, Mis 25.8 and yellow 41.1. Fifteen prefer Mas, five Mis, one Ma, ten yellow, six red, six white. Of the visits of Epeolidæ 15.6 per cent are to Labiatæ and 58.5 to Compositæ.

Nomadidae.-Of 272 visits to 108 flowers 48.5 per cent are to Mis, 31.9 to $\mathrm{Mi}, 51.1$ to white, 36.3 to yellow, 14.7 to Compositæ, 14.3 to Salix and 11.7 to Rosaceæ. Being inquilines at least principally of Andrenidæ they are associated with them in time and place and naturally show similar flower visits. Sixteen prefer Mis, four Mi, two Mas, 14 white, nine yellow.

Melectoidea.-Of the 481 visits, 38.6 per cent are to Mis, 33.4 to Mas, 41.7 to white and 38.4 to yellow. The Nomadidæ make only 17 visits after June, and the other Melectoidea make only five visits before July, so that their differences are largely phenological. Before July they prefer Mis, Mi, yellow and white; after June, Mas, Mis and yellow. The maxima shift from $\mathrm{AB} 32.6$ to $\mathrm{B}^{\prime}$ 58.9, Mis 45.7 to Mas 66.0 , white 50.5 to yellow 39.6.

Megachilinoe.-The Megachilini (331 visits to 151 flowers) prefer Mas, Mis, red 40.1 and yellow 33.3. The flowers visited 
show Mas 33.1, Mis 26.4, while the visits show Mas 53.8, Mis 16.1. Visits to red in Low Germany are 67.0 per cent and the Berlin Garden 74.0.

Of 110 visits of Colioxys to 62 flowers, 54.5 per cent are to Mas, 28.1 to Mis and 36.3 to yellow. Loew $(\mathbf{2}, 264)$ calls it an oligotrope of red colors, but it shows 30.0 under red compared with 60.0 in the Berlin Garden and 66.0 in Low Germany. Of visits to red the females show 42.2 and the males 28.9 .

Nineteen species of Megachilinæ prefer Mas, three Ma, 11 red, nine yellow and two white. Of their visits 12.8 per cent are to Labiatæ, 17.5 to Leguminosæ and 39.5 to Compositæ. The maximum changes from $\mathrm{Hb} 50.3$ before July to $\mathrm{B}^{\prime} 42.0$ after June.

Osmiince.-Of 295 visits to 138 flowers, 27.7 per cent are to $\mathrm{Ma}, 27.4$ to $\mathrm{Mi}, 48.1$ to white, 15.2 to Leguminosæ, 11.1 to Rosaceæ and 10.3 to Polemoniales. Seven prefer Mi, 41.8 per cent of visits, 5 Ma $66.6,5$ Mas $41.3,3$ Mis 57.1, 13 white 52.6, 5 red 43.3, 2 yellow 66.6. Local visits to red are 27.4 per cent, Berlin Garden 65.0 and Low Germany 77.2. Visits to Mas show for the females 22.6, for the males 6.2. Before July the Osmiinæ prefer Ma, Mas, Mi, white and red; after June, Mas, Mis, white and yellow. The maxima shift from $\mathrm{Hb} 43.7$ to $\mathrm{B}^{\prime} 48.9$, Mi 32.8 to Mas 57.4.

Anthidiini.-Of 9 visits to 8 flowers, 88.8 per cent are to Mas, 44.4 to red and 33.3 to yellow. Visits to red in Low Germany are 72.7 and in the Berlin Garden 87.0.

Stelidini.-Of 17 visits to 16 flowers, 76.4 per cent are to Mis, 58.8 to white, 41.1 to yellow, 58.8 to Compositæ. In the Berlin Garden 41.6 per cent of the visits were to red.

Dasygastro.-Of 812 visits made by the last four groups, 40.8 per cent are to Mas, 33.3 to red, 10.3 to Labiatæ, 15.6 to Leguminosæ and 30.7 to Compositæ. Of the visits of the nestmakers 18.2 per cent are to Mis, 34.1 to red and 61.9 to social flowers; while of the visits of the inquilines 34.6 per cent are to Mis, 35.6 to yellow and 90.4 to social flowers. Before July (Osmiinæ 256 visits, Megachilinæ 133) they prefer Mas and red; after June (Osmiinæ 47, Megachilinæ 389) Mas, yellow and red. The maxima shift from $\mathrm{Hb} 44.8$ to $\mathrm{B}^{\prime} 43.4$, Ma 27.2 to Mas 57.2 , white 43.3 to red 36.4 . 
Müller $(4,55)$ says: "More than nine-tenths of the flowers visited by bees with abdominal brushes are such as are adapted to dust the ventral surface of the bee with pollen (Echium, Papilionaceæ, Compositæ, etc.) without any action of the tarsal brushes. More rarely, bees with abdominal brushes may be seen feeding on flowers whose pollen gets applied to their backs; in such cases the bee makes use of its tarsal brushes to sweep off the pollen from the parts where it has fallen into the abdominal brushes." Considering the composition of the flora Müller's statement shows about what these bees would be expected to do without preference. Of 243 local flowers visited for pollen by long-tongued bees in general, only 11.1 per cent require the use of the tarsal brushes. Of 146 visited for pollen by the Dasygastræ, 5.2 per cent require the use of the tarsal brushes. It is not easy to separate such flowers, because the Dasygastræ often reverse on nototribe flowers so as to receive the pollen on their undersides, as in the case of Linaria vulgaris, Pentstemon, Impatiens and Pinguicula. They also reverse on some species of Gerardia and Viola, but these flowers compel them to turn head downwards. On tubular flowers with included anthers they collect the pollen which adheres to their tongues, Lithospermum canescens, Verbena stricta.

Compared with other groups the Dasygastræ show a marked predilection for sternotribe flowers, 47.5 per cent of thei pollen visits. They do not equal the Euceridæ in their prefererence for Compositæ or antipathy to nototribe flowers.

Müller $(\mathbf{4}, 55)$ further says: "There can be little doubt therefore that the bees with abdominal brushes have adapted themselves to the flowers which were fitted to dust their ventral surfaces (Papilionaceæ, Compositæ, Echium, etc.), and the contrary view, that these flowers have become adapted to the bees, is untenable, for the flowers are visited and fertilized by other and far more numerous insects." The Dasygastræ and Papilionaceæ have July maxima. There are several sternotribe flowers of which these bees are the most important and almost exclusive visitors.

Panurgida.-Of 141 visits to 84 flowers, 44.6 per cent are to Mas, 31.9 to Mis, 50.3 to yellow and 60.2 to Compositæ. 
Red shows 31.3 per cent of the flowers visited and 19.8 per cent of the visits. Yellow shows 33.7 per cent of the flowers. Nine prefer Mas, five Mis, two Mi, ten yellow, four white and two red. Before July they prefer Mas, Pol and red; after June, Mas, Mis and yellow. The maxima shift from $\mathrm{Hb} 35.7$ to $\mathrm{B}^{\prime}$ 66.6, red 39.2 to yellow 55.8 . The heterotropy is given in 7, 172-3.

Halictidæ (ex. Sphecodini).-Of 1840 visits to 287 flowers, 41.8 per cent are to Mis, 28.5 to $\mathrm{Mi}, 51.3$ to white, 33.4 to yellow and 21.6 to Compositæ. Mis shows 30.3 per cent of the flowers visited. Visits of females show Mi 30.8, Mas 13.4; of males, Mi 10.0, Mas 27.1. Visits to red are 15.2 per cent, Low Germany 35.6 and Berlin Garden 38.0.

Loew $(\mathbf{2}, 71)$ calls Halictidæ males oligotropes of $B^{\prime}$. The males begin to fly about June 4 and are limited mainly to flowers observed after June, when the Halictidæ in general make a smaller percentage of visits to $\mathrm{B}^{\prime}$ than any other short-tongued bees, except Prosopis. The percentage of visits to $\mathrm{B}^{\prime}$ after June is for the females 36.3 , while that for the males is 39 . The females make pollen visits to many deep tubed Compositæ on which the males do not occur.

Sphecodini.-Of 111 visits to 57 flowers, 54.9 per cent are to Mis, 33.3 to Pol, 63.9 to white, 35.1 to yellow, 27.9 to Umbelliferæ, 18.9 to Compositæ, and 10.8 to Labiatæ. Visits to red are 0.9 per cent, in Low Germany 26.7.

Halictida.-O 1951 visits of the Halictidæ in general, 42.5 per cent are to Mis, 27.5 to $\mathrm{Mi}, 52.0$ to white and 33.5 to yellow. Of 165 non-pollinating visits, 53.7 per cent are to Ma, 37.5 to Mas and 52.1 to red. Forty prefer Mis, six Pol, six Mi, three Mas, 38 white, 17 yellow and only one red. Before July they prefer Mis, Pol, Mi, yellow and white; after June, Mis, Pol and white. The maximum shifts from $\mathrm{AB} 37.2$ to $\mathrm{B}^{\prime} 37.6$.

Andrenidce.-Of 585 visits to 133 flowers, 59.6 per cent are to Mis, 54.4 to white, 40.0 to yellow, 18.6 to Rosaceæ, 15.7 to Salix, 12.8 to Umbelliferæ and 11.4 to Compositæ. Mis shows 37.5 per cent of the flowers visited. Red shows 5.4 per cent of local visits, in Low Germany 26.0 and Berlin Garden 46.7. Thirty-seven prefer Mis, four Mas, four Ma, four Mi, 28 white, 
19 yellow and four red. Before July they prefer Mis, Pol, white and yellow; after June, Mis, Mas and yellow. The maxima shift from $\mathrm{AB} 50.5$ to $\mathrm{B}^{\prime}$ 86.2, Mis 60.7 to Mas 50.0, white 56.9 to yellow 56.8 .

Prosopidida.-Of 166 visits to 74 flowers, 61.4 per cent are to Mis, 24.7 to Pol, 68.6 to white, 34.9 to Umbelliferæ, 16.8 to Compositæ and 12.6 to Rosaceæ. Visits to red are 0.6 per cent, Berlin Garden 32.5, Low Germany 36.7. Eight prefer Mis, and one Mi. Before July they prefer Mis, Pol, white and yellow; after June, Mis, Pol and white. The maximum shifts from A 40.5 to $\mathrm{B}^{\prime} 31.2$.

Colletidoe.-Of 140 visits to 89 flowers, 52.1 per cent are to Mis, 15.0 to Pol, 50.0 to white, 39.2 to yellow, 14.2 to Umbelliferæ and 37.1 to Compositæ. Seven prefer Mis, four Mi, three Mas, seven white, five yellow and three red. Under Mas the females show 22.0 per cent, while the males show only 8.6. Before July there is a maximum of 34.3 under B, after June it changes to 58.7 under $\mathrm{B}^{\prime}$.

Long-tongued Bees.-Of 3061 visits to 370 flowers, 37.7 per cent are to Mas, 22.1 to Mis, 34.0 to red, 31.4 to yellow, 10.5 to Leguminosæ and 30.3 to Compositæ. Of the flowers visited and visits Ma shows 32.4 and 23.6, while Mas shows 22.4 and 37.7. Visits to red in the Berlin Garden are 60.4, in the Alps 63.3. Seventy prefer Mas, $31 \mathrm{Ma}, 11 \mathrm{Mi}, 60 \mathrm{red}, 43$ white, 43 yellow. Before July they prefer Mas, Ma, Mis and red; after June, Mas, Mis, yellow and red. Visits after June show the preferences probably better than the general visits because the majority of long-tongued bees are late. The maxima shift from $\mathrm{Hb} 43.0$ to $\mathrm{B}^{\prime} 46.9$, Ma 31.5 to Mas 56.9 , white 43.5 to red 37.8 .

Of the visits of the polyleges 32.5 per cent are to Mas, 30.8 to $\mathrm{Ma}$ and 37.0 to red; of the inquilines 38.4 to Mas, 36.3 to Mis, 35.8 to yellow and 40.4 to white; of the. oligoleges 68.2 to Mas, 45.5 to yellow and 36.2 to red. The polyleges show the highest percentages to $\mathrm{Ma}$ and red, the oligoleges to Mas and yellow, and the inquilines to Mis and white. The oligoleges show the highest percentage of visits to social flowers, 86.0, and the polyleges to non-social 43.9. Forty-two prefer non-social flowers. Non-pollinating visits (66) show for Ma 68.1, Mas 28.7 
and red 56.0. The long-tongued bee visits show gains over the short-tongued of 19.6 for Ma, 23.8 for Mas and 22.1 for red.

Short-tongued Bees.-Of 3002 visits to 305 flowers, 46.7 per cent are to Mis, 24.4 to $\mathrm{Mi}, 10.8$ to Pol, 52.1 to white, 35.8 to yellow, 10.8 to Umbelliferæ and 21.9 to Compositæ. Of the flowers visited Mis shows 29.1 per cent and Mi 32.1. Ninetyseven prefer Mis, $20 \mathrm{Mas}, 18 \mathrm{Mi}, 6 \mathrm{Pol}, 4 \mathrm{Ma}, 87$ white, 53 yellow and ten red. Visits to red are 11.9 per cent, Berlin Garden 34.3, Alps 36.2. There is a preference for Mas after June. The maximum changes from $\mathrm{AB} 39.1$ to $\mathrm{B}^{\prime}$ 44.1. Of the visits of the polyleges (Prosopis excluded) 44.6 per cent are to Mis, 27.9 to Mi, 9.3 to Pol, 52.8 to white, 33.3 to yellow; of the oligoleges 49.7 to Mis, 31.7 to Mas, 7.1 to Pol, 55.3 to yellow; of the inquilines 58.7 to Mis, 29.3 to Pol, 62.7 to white and 36.5 to yellow. Their preference for $\mathrm{Mi}$ connects the short-tongued bees pretty definitely with the origin of these most primitive entomophilous flowers.

The short-tongued bees, compared with the long-tongued, show preferences for Mi 12.4, Mis 24.6, Pol 6.4, white 17.6 and yellow 4.4. Non-pollinating visits (192) show under Ma 56.7, Mas 38.5 and red 53.6.

Bees, Total (6063 visits to 417 flowers).- Of bee visits 34.2 per cent are to Mis, 25.7 to Mas, 43.2 to white and 33.5 to yellow, 127 preferring Mis, $93 \mathrm{Mas}, 35 \mathrm{Ma}, 29 \mathrm{Mi}, 6 \mathrm{Pol}, 130$ white, 96 yellow and 70 red. Visits to red are 23.1 per cent, Berlin Garden 55.4 and the Alps 57.1. As might be expected, bee visits coincide more nearly with the observed flora than the visits of any other group of anthophilous insects.

Before July the bees prefer Mis, after June they prefer Mas. The change in the maximum from Mis 38.1 to Mas 45.2 results from the combination of the short-tongued bees which predominate early with the long-tongued bees which predominate late. The maximum shifts from AB 29.9 to $\mathrm{B}^{\prime} 45.7$.

The polyleges (Prosopis excluded) make 73.3 per cent of the total bee visits. They show the highest percentages of visits to Ma 16.9, Mi 21.0, red 24.6 and white 44.6, the oligoleges to Mas 50.0 and yellow 50.4, and the inquilines to Mis 39.9 and Pol 8.5. 
Of the visits of bees 13.9 per cent are to $\mathrm{Ma}$ and these are 81.6 per cent of the total visits to that class. Bees show the highest percentages of visits to flowers of all classes, except Pol, and to all colors, Ma 81.6, Mi 59.7, Mas 54.7, Mis 37.3, red 59.7, white 36.6, yellow 45.9. They are 22.9 per cent of the insects observed and make 43.3 per cent of the visits.

According to the general visits the long-tongued bees show a preference for Mas 19.0, for Mis 0.6. In the case of 61 flowers on which the individuals were taken as they came, they showed a gain over visits for Ma 8.9 and Mas 15.4. The short-tongued bee visits show a preference for Mis 25.2, Pol 5.6 and Mi 0.2. The individuals show a gain over visits for Mis, 33.1. So the characteristic differences between long-tongued and short-tongued bees are better indicated by counting the individuals than by counting the visits.

\section{Literature Cited.}

1. Knuth, P. Handbook of flower pollination. 1:1-382. (1906). Transl. of Handbuch der Blütenbiologie. 1898.

2. Loew, E. Beobachtungen über den Blumenbesuch von Insekten an Freilandpflanzen des Botanischen Gartens zu Berlin. Jahrb. K. bot. Gart. Berlin. 3:69-118, 253-9. (1-94). 1884.

3.........Weitere Beobachtungen u. s. w. Jahrb. k. bot.

Gart. Berlin. 4:93-178. 1886.

4. Müller, H. The fertilisation of flowers. (1883). Transl. of Die Befruchtung der Blumen. 1873.

5. ......... Die Alpenblumen, ihre Befruchtung durch Insekten und ihre Anpassungen an dieselben. 1881.

6. Robertson, C. Flowers and insects. I-XXII. Botanical Gazette 1889-1923.

7. .......... Synopsis of Panurgidæ. Psyche 29:159-173 1922. 

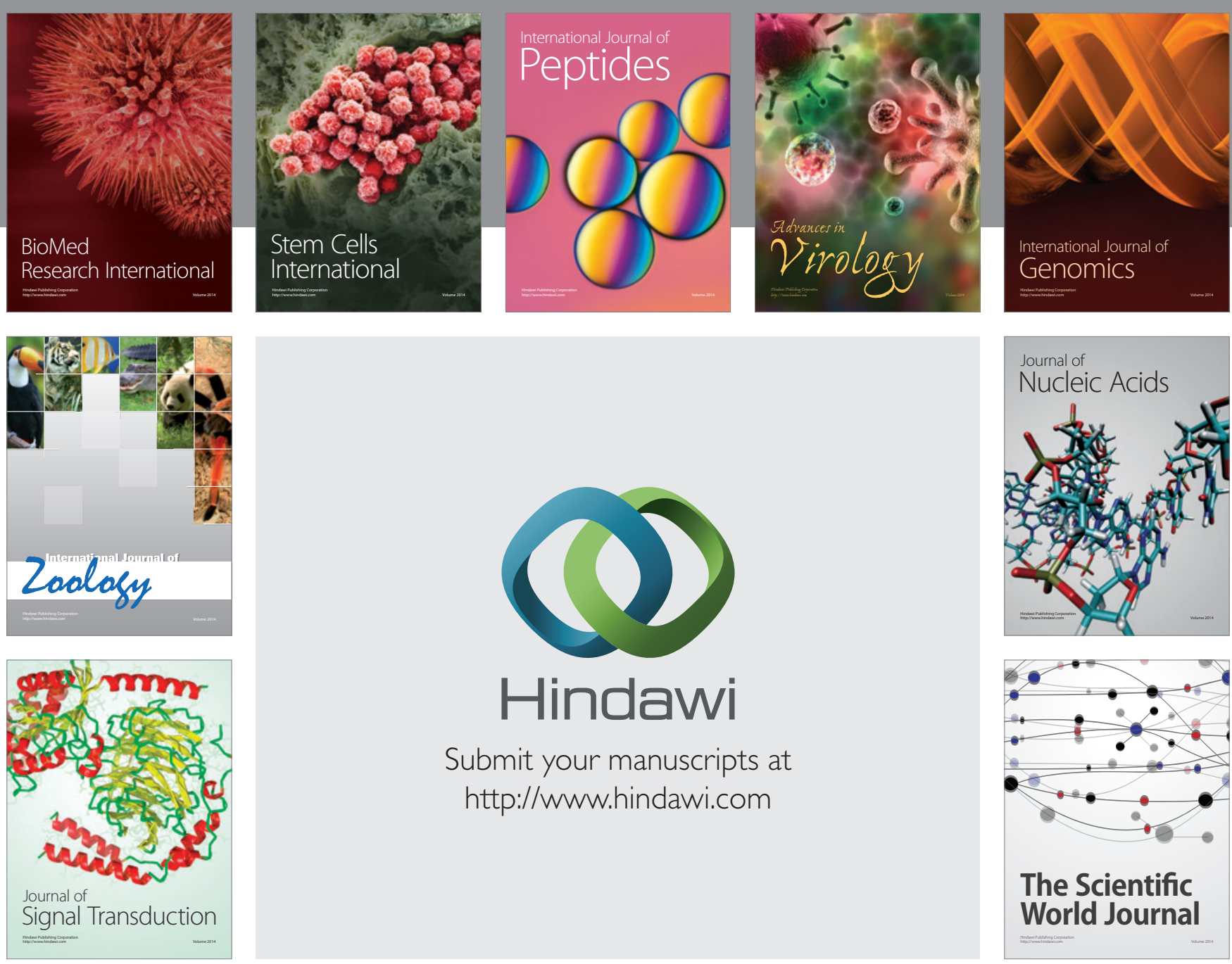

Submit your manuscripts at

http://www.hindawi.com
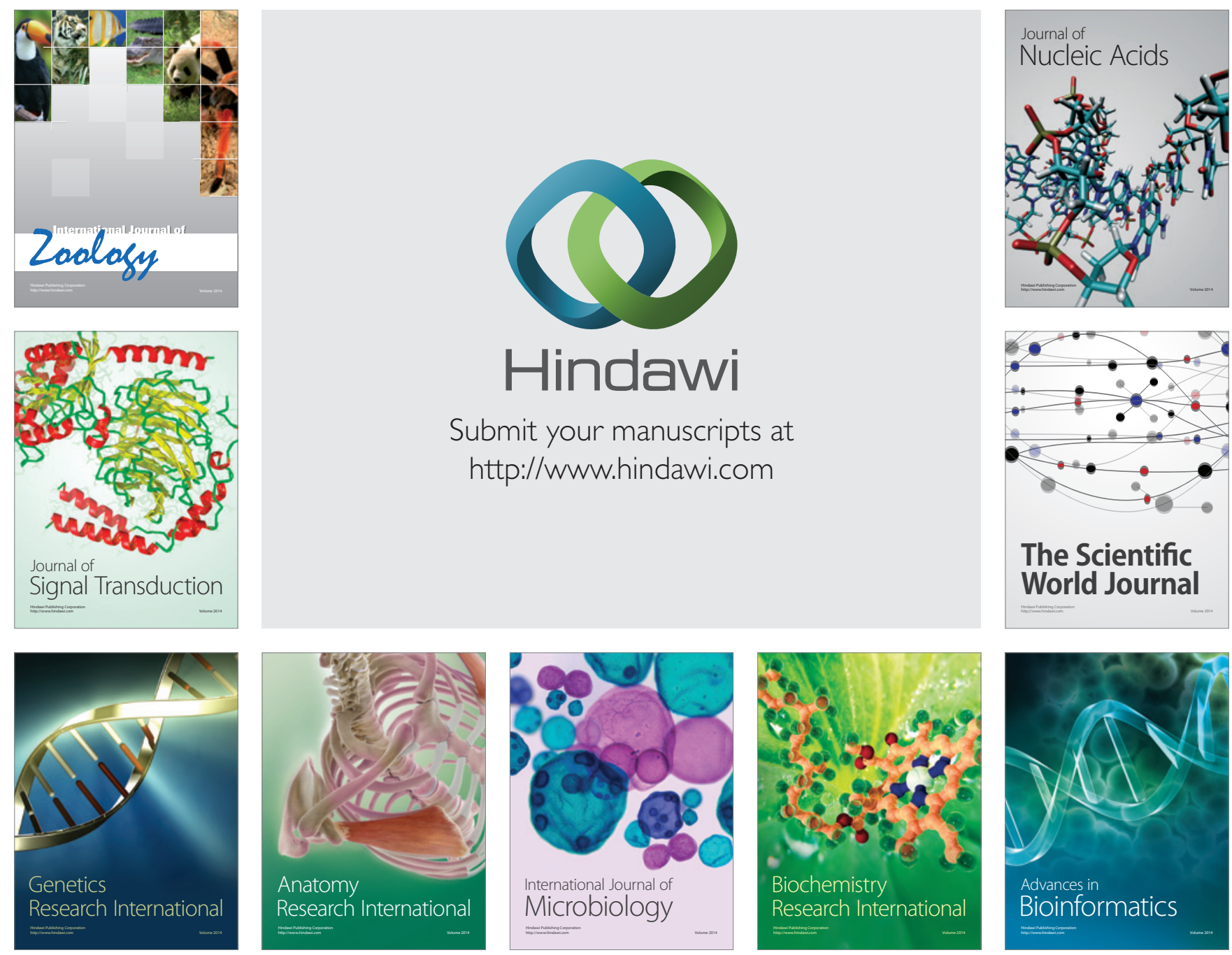

The Scientific World Journal
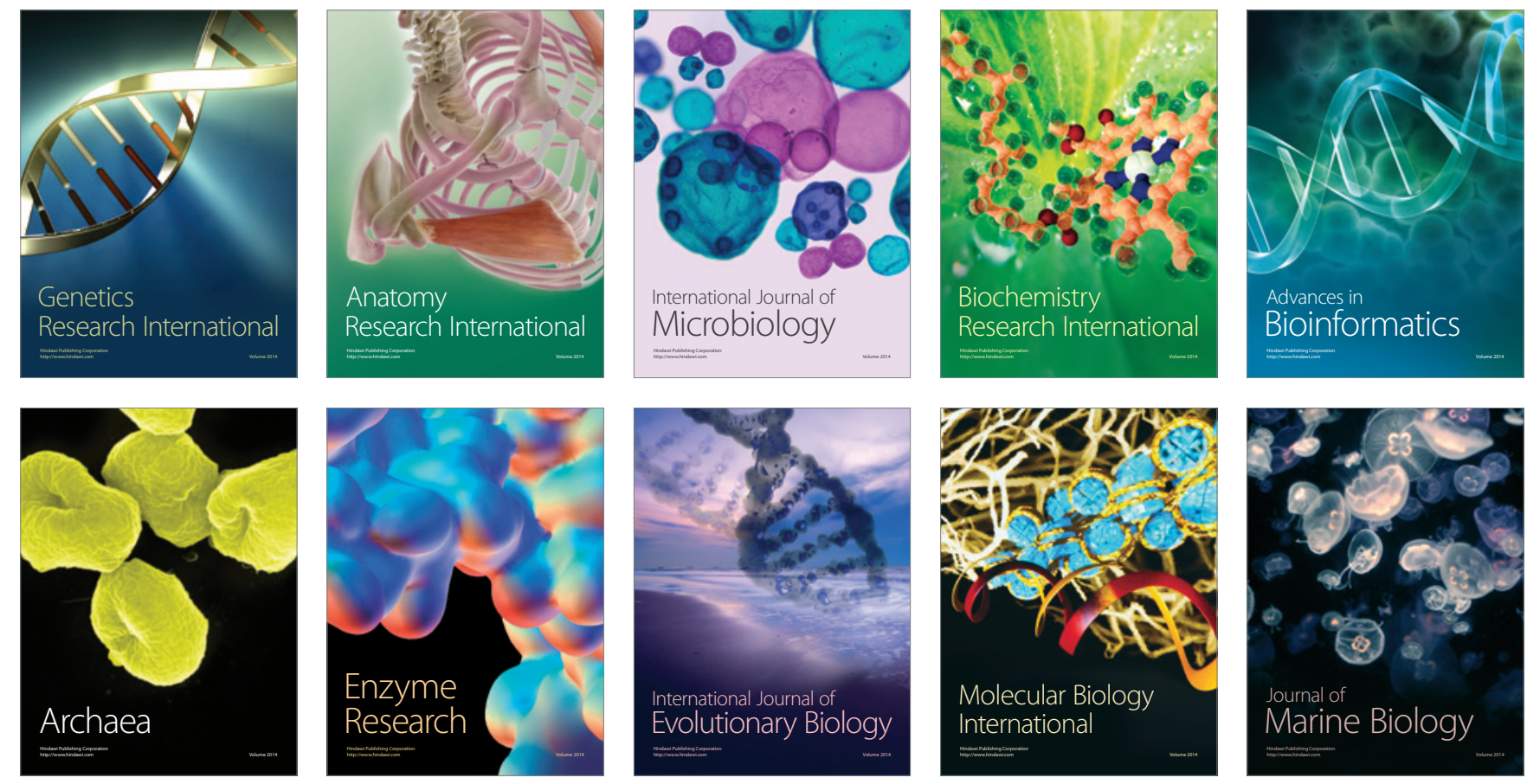